\title{
Nano's Big Bang: \\ Transforming Engineering Education and Outreach
}

\author{
C. L. Alpert, J. A. Isaacs, ${ }^{*}$ C. M. F. Barry, ${ }^{\sharp}$ G. P. Miller, ${ }^{\S}$ A. A. Busnaina* \\ Museum of Science, Boston / *Northeastern University / \\ ${ }^{\#}$ University of Massachusetts Lowell $/{ }^{\S}$ University of New Hampshire
}

\begin{abstract}
The rapid emergence of nanoscale science and engineering as a focal point for a broad range of government and privately-sponsored basic research activities - intended to catalyze breakthrough technologies and commercially-successful advances in medicine, computing, materials, manufacturing and defense- is having a correspondingly influential impact on the design of engineering education and outreach programs aimed at university, K-12, and public audiences. This paper examines the nature of this influence as well as the opportunities and challenges it presents to education and outreach professionals, in light of current trends in STEM education. The authors are involved in a collaborative effort to devise strategies to tackle some of these challenges through the design and development of the education and outreach aspects of the Center for High-Rate Nanomanufacturing (CHN), an NSF-sponsored Nanoscale Science and Engineering Center (NSEC). Close collaboration among CHN's science, engineering and societal implications researchers, university and K-12 educators, and science museum public engagement specialists, is expected to lead to new models for integrating research, education, outreach, and public engagement within the context of the National Nanotechnology Initiative.
\end{abstract}

Introduction: Nanotechnology Now

“The future ain't what it used to be..." - Yogi Berra

It is becoming increasingly likely that a few decades from now we will be living in a world fundamentally transformed by nanotechnology. At stake for humanity are potential breakthroughs in energy production and storage, medicine and biotechnology, computing, communications, transportation, housing, environmental protection, and defense. Maintaining a leadership position in global technology R\&D is also of critical importance to the U.S. economy. A race is on to patent and exploit key techniques and processes that will ensure healthy participation in the coming worldwide nanotech economy, which is estimated to approach \$1 trillion within the decade. ${ }^{1}$

The interdisciplinary nature of this oft-characterized " 21 st century industrial revolution" will likely inspire as well as require new developments in the way science and engineering are taught nationwide. Government and industry leaders are already expressing concern about filling the pipeline with next generation nano researchers, engineers, technicians, and commercial product developers. Efforts to reform and advance engineering education have taken on new urgency

"Proceedings of the 2005 American Society for Engineering Education Annual Conference \& Exposition Copyright (C2005, American Society for Engineering Education” 
and drawn more concentrated support as they have become more closely aligned with the nation's nanotech initiative, which is also stimulating increased investment in basic research in physics, chemistry, biology, medicine, and materials science.

At the same time, nanotech R\&D boosters have become more acutely aware of the nation's need to make concomitant progress on the associated health, safety, environmental, regulatory, economic, workforce, ethics, and other societal issues that emerge alongside the development of any transformative technology; in this case, nanotechnology. Indeed, the National

Nanotechnology Initiative (NNI) has taken an unusually proactive approach to anticipating and funding research in these areas, commonly grouped together as "societal implications of nanotechnology" Two key NNI strategies are to (1) catalyze systemic educational reform reflective of the new interdisciplinary science and engineering landscape, and (2) to engage the public at large, involving citizens in discussion of related societal issues. ${ }^{3}$

These priorities lead even seasoned veterans in both the K-16 and informal science and engineering education realms to consider at some depth what fundamental differences, if any, in engineering education and public outreach are called for when the topic at hand is nanoscale science and engineering.

Nanoscale Science and Engineering: What's New?

\section{“This is like déjà vu all over again” - Yogi Berra}

Indeed, skeptics within the academy argue that the term "nanotechnology" is little more than a new way to market and revitalize research programs in fields spanning the gamut from materials science, photonics, medicine, space research, physics, chemistry, and computer science. Notwithstanding this flavor of seasoned cynicism surrounding the politics of funding scientific research, one can still characterize features that tend to distinguish work in the nanoscale realm. To wit, nanoscale science and engineering:

- Focus on working with structures 10 to $100 \mathrm{~nm}$ in size.

- Involve characterization of properties of matter and forces that become increasingly significant at the nanoscale, e.g., quantum effects and van der Waals forces.

- Offer opportunities to manipulate these nanoscale properties and forces so that new material properties emerge on a macro scale.

- Require interdisciplinary knowledge at least on a team level, with expertise often required in quantum physics and theory, chemistry, electrical engineering, computer modeling, advanced imaging and instrumentation, photonics, materials science, biology and biochemistry, and engineering.

- Intensify engineering interest in biological systems that operate as models of tiny molecular motors or assemblers.

- Require new generations of instruments for the high-resolution imaging and manipulation of matter at the nanoscale.

- Afford opportunities to build new materials and devices from the bottom-up (atom by atom) as well as from top down.

"Proceedings of the 2005 American Society for Engineering Education Annual Conference \& Exposition Copyright (C)2005, American Society for Engineering Education” 
- Raise new types of health and environmental safety concerns due to the paucity of prior experience working with nanoscale materials.

- Raise economic and workforce concerns because of the uncertainty over changing investment and production environments and markets surrounding nanotechnology.

- Provide fertile ground for science fiction writers and future prognosticators, often stimulating public concern over the cost of tinkering in this new world prior to achieving full understanding of all the potential consequences.

Whether nanoscale science and engineering will lead to a truly paradigm-shifting new "industrial revolution" or simply to a further acceleration in the evolution of our ability to detect, manipulate, and construct smaller and smaller entities and devices, remains to be seen. ${ }^{4}$ In the meantime, it is clear that the national nanotech enterprise is serving as a catalyst for revamping engineering education and outreach practices and for developing new approaches toward public engagement with research.

\section{Engineering Education in an Emerging Nanotech World}

\section{"I skate to where the puck is going, not to where it's been." - Wayne Gretzky}

Progress in nanotech is driven by its big potential payoffs in materials science, computing, medicine, manufacturing, consumer products, and defense. Basic research in the nanoscale is multidisciplinary. Thus, the big push in nanotechnology is accelerating a break down of traditional boundaries between once-distinct science and engineering disciplines in university and industry R\&D departments, and helping to catalyze the anticipated "NBIC" convergence (nano-bio-info-cogno). ${ }^{5}$

Taking a historical view, one can see the seamless convergence of the physical, chemical, and biological sciences as a goal long sought by positivist visionaries who predicted a gradual erasure of the gaps in causal knowledge between each discipline, ultimately leading to a kind of engineering paradise in which even complex human and social behavior could be broken down and made predictable to the level of atoms and electrons and perhaps further. While such extreme reductionist thinking ran into roadblocks bounded on the small end by the indeterminance of quantum phenomena and on the large end by emergent systems dynamics, the lure of an all-inclusive answer to the question of how things work continues to tempt many of the more ambitious theorists. Instead, if anything, nanoscale science and engineering have demonstrated only more clearly the marked discontinuity at the small end of the perceptual scale. Materials in the nano realm behave nothing like their larger counterparts, and the differences are often startling and difficult to explain. The true wonder is how such a solid and logical appearing world has somehow condensed from such a wild set of seemingly inexplicable fundamental forces.

Nevertheless, the physics-chemistry-biology-computational-convergence at the nanoscale has forced scientists to consort more closely with engineers and other applied scientists and vice versa. After all, as Heisenberg made clear, it is impossible to even perceive what is going on "down there" without manipulating it in some way. The really exciting frontiers in all of these

"Proceedings of the 2005 American Society for Engineering Education Annual Conference \& Exposition Copyright (C)2005, American Society for Engineering Education” 
fields involve interdisciplinary understandings that blur previous academic and professional distinctions. Science and engineering are simply the yin and yang of knowledge and know-how.

What does all this mean for engineering education? First of all, engineers will need a far greater range of basic science coursework - especially in chemistry and biology - than currently exist in most curricula. Second, there is increasing demand to produce both scientists and engineers with better business know-how and the ability to envision shaping basic research into marketable products. Third, there is growing consensus that engineers need to gain a broader perspective on STS (science, technology and society) issues.

Yet, as any university engineering professor can tell you, there is little room in the engineering curriculum for extra coursework. ${ }^{6,7}$ The bottleneck has led many to inquire whether the introductory college-level math and science courses be "offloaded" or "down-sourced" to the secondary school level. This could potentially provide curricular "space-time" for about 8 to 10 additional college level courses. Indeed, in many industrialized countries, the algebra-geometrytrigonometry-calculus sequence is taught several grades earlier than in the U.S. ${ }^{8,9,10}$ A key roadblock to adopting such a strategy here would be our national acquiescence to low standards for the training of STEM teachers at the K-8 level. Getting around this roadblock would require serious political will and investment in better training, curricular reform and competitive salaries for the nation's schoolteachers.

On the other side of the training continuum, there is little incentive to extend collegiate engineering programs to 5 or 6 years, as is done in architecture, for example. Although the M.S. may still emerge as the professional degree of choice, the job market is currently strong enough to counter any such trends. U.S. engineering students are less likely than foreign students to study full-time for M.S. and Ph.D. degrees. ${ }^{11,12}$ This may be due partially to the pressure of debt loads incurred for undergraduate degrees, as well as to the growing job market for engineers, which seems to offer little in the way of wage incentives for bearers of more advance degrees.

Given the rapid pace of development of new engineering techniques and processes, particularly now at the nanoscale, the four-year program will likely fall farther behind in adequately preparing engineers for the new level of sophistication required for frontier areas in nanotech and nanomanufacturing. The traditional stop-gap measure for universities and industry is to forge collaborations that provide life-long training opportunities for industry engineers to upgrade skills and knowledge. For example, the engineering college at the University of Massachusetts Lowell offers industrial seminar series for mid-career engineers on plastics and toxics usereduction. These sessions typically last between one-day and one week, are well-attended, and are offered on-site per company request. Such ad-hoc approaches at engineering schools, however, are often scattered and somewhat serendipitous, providing neither a broad base of fundamentals nor the preferred in-depth focus.

This classic tension between depth and breadth in engineering education is especially vivid at the undergraduate level, given the tight four-year time frame and the lack of adequate secondary school preparation. The advent of nanotechnology, with its sweeping interdisciplinary horizon, has heightened the tension. Should engineering programs broaden the base of fundamentals for each student so as to better inform their total practice, letting specialization come later, or,

"Proceedings of the 2005 American Society for Engineering Education Annual Conference \& Exposition Copyright (C)2005, American Society for Engineering Education” 
should faculty foster key individual competencies through deep and thorough immersion and specialization, relying on interdisciplinary team approaches in actual practice to provide the necessary contextual whole? This is a difficult debate to settle to anyone's satisfaction, especially with the four-year college program time-squeeze. Stanley Williams of HewlettPackard argues that true breakthroughs require teams in which individual members are thoroughly immersed in the complexities of their subspecialties; he fears that the interdisciplinary approach will lead to teams with great breadth of knowledge but shallow and homogenized abilities. ${ }^{13}$ Others argue that the benefits of breadth are incalculable - that even a little bit of cell biology, for example, can provide realms of inspiration for a microelectromechanical systems builder.

The current trend seems to be weighted toward increasing interdisciplinarity at the undergraduate level. Partly stimulated by the promise of nanotechnology, NSF is actively funding the development of new types of curricula that openly embrace interdisciplinary convergence-type learning ${ }^{14}$. Many universities are introducing nanoscale science and engineering curricula that survey the major approaches and touch lightly on the many subspecies of nano efforts. The Accrediting Board for Engineering and Technology in 2000 also recommended crossdisciplinary components in engineering. Students must be prepared for engineering practice based on the knowledge and skills acquired in earlier course work and incorporating engineering standards and realistic constraints that include most of the following considerations: economic, health and environmental, sustainable, manufacture-able, ethical, societal and political. ${ }^{15}$

Even university-based mid-career training programs offered to industry engineers - which traditionally provide in-depth state-of-the-art training in particular engineering sub-specialties are also now beginning to include broad introductory overviews of the nano field. The University of Massachusetts Lowell, for example, will start a cross-disciplinary graduate certificate in nanotechnology and nanoscience in Fall 2005, designed for industry workers as well as more traditional students. The four-course Certificate includes two required courses (an overview of nanotechnology and a nanoscale characterization course) and two electives selected from courses in four tracks: materials, manufacturing, design and devices, and health and environmental impacts. Since the Certificate is not a new major, all the courses are offered by specific departments or as interdisciplinary engineering courses, and interested students can also use these courses for graduate degrees in traditional disciplines. The University of Massachusetts Lowell has successfully employed this approach for other interdisciplinary graduate certificates, such as "biomedical engineering" and "medical plastics design and manufacturing," because the Certificates are suited to students with a wide range of science and engineering backgrounds and the courses are easily transferable to existing degree programs or new concentrations within these programs.

NSF is also actively soliciting collaborations between engineering faculty, social scientists and humanists to build into engineering curricula additional units on societal implications, costbenefit assessments and applied ethics. ${ }^{16}$ NSF will also be awarding this year a large center grant for research into the societal implications and ethical considerations related to nanotechnology. ${ }^{17}$ In the meantime, individual nanoscale research centers are designing their own approaches to weaving such considerations into their educational practice. For instance, Northeastern University faculty associated with the Center for High-Rate Nanomanufacturing are

"Proceedings of the 2005 American Society for Engineering Education Annual Conference \& Exposition Copyright (C)2005, American Society for Engineering Education” 
developing ethics workshops for nanotech students as well as mid-career industry professionals. The goals of the workshops are to introduce the AIR (awareness, investigation and response) model ${ }^{18}$ of ethical inquiry to participants. This model will be presented both as a proven tool to assist them in processing the ethical issues that may arise during their own laboratory research, and as a teaching tool for use with the students, graduate assistants, technicians under their supervision.

$\mathrm{CHN}$-affiliated faculty at the University of Massachusetts Lowell are designing curricula that use nanotechnology as a framework for examining the entire range of societal issues associated with emerging technologies. For example: faculty in the Department of Work Environment plan to offer a new course focusing on worker health, safety, and regulatory issues to undergraduates in the physical sciences and engineering; faculty teaching a course on engineering ethics have started to incorporate nanotechnology cases; a faculty member in English has even added a critical review of nanotech science fiction dystopias to his popular course, "Monsters, Apes, and Nightmares."

\section{Secondary School Education in an Emerging Nanotech World}

"We must educate people on what nobody knew yesterday and prepare people in our schools for what no one knows yet, but what some people must know tomorrow." - Margaret Mead

The crunch in university engineering curricula would be relieved of course if students were better prepared going in. We have already discussed the advantage that would be gained if mathematics curricula were more rigorous on the secondary level. Another fairly radical idea is emerging - that of introducing engineering-oriented curricula directly into K-12 education. Christine Cunningham, Vice President of Research at the Museum of Science points out that even though "our society is increasingly dependent on technology and engineering, citizens have little understanding of how the human-made world that surrounds them is created or functions. Perhaps, therefore, K-12 schools should not only educate students about the natural world, but also the human-made world." ${ }^{\prime 19}$ Proponents of this approach argue that not only is engineering literacy increasingly vital to our advanced technology society, but also that giving students at a younger age the opportunity to play with the real-life, problem-solving, design-challenge aspects of engineering will foster students' intrinsic motivation to tackle science and math and to envision future careers in science and engineering. The importance of this kind of motivation cannot be overstated, given the depressing national trend in STEM education.

In 2002 only $6 \%$ of all US high school students planned to study engineering, a decline from $9 \%$ polled in $1992 .{ }^{20}$ While women and minority student participation has increased, they are still proportionally underrepresented in the field. ${ }^{21}$ A major determinant of whether secondary students even enroll in higher education turns out to be their continuance, in high school, of upper level math courses. ${ }^{22}$ However, even those students who enroll in STEM courses tend not to choose STEM careers. Recent studies show that ignorance about careers in engineering may account for a great deal of the lack of student motivation in this area. "23 "One of the problems," says Claire Duggan, Associate Director for the Center for the Enhancement of Science and Mathematics Education (CESAME) at Northeastern University, "is that neither STEM teachers

"Proceedings of the 2005 American Society for Engineering Education Annual Conference \& Exposition Copyright (C)2005, American Society for Engineering Education” 
nor high school guidance counselors have a clear understanding of what engineers do, and so have trouble communicating this to their students. ${ }^{24}$ Meanwhile, "Learning for the Future: Changing the Culture of Math and Science Education to Ensure a Competitive Workforce," released by the Committee For Economic Development (CED), a business group, focused on three issues: lack of interest in scientific and technological careers among young people, poor quality of coursework, and inadequate teacher training. ${ }^{25}$ Teachers in math and science courses are often teaching out-of-field. Almost a third of high school mathematics classes are taught by teachers who do not have a major or minor in mathematics." In fact, most Americans fail to grasp the role of engineers and engineering in society. ${ }^{26}$ This lack of understanding may suggest that emphasis be placed on informing guidance counselors as well as teachers about careers in engineering, but most students have fairly infrequent meetings with their guidance counselors.

Robert Chang, Director of the Materials Research Institute at Northwestern University and Principal Investigator for the National Center for Nanoscale Learning and Teaching in Nanoscale Science and Engineering, argues further that engineering career information programs should target the parents of secondary school students. He points out that while there are at least some outreach programs that target students, teachers, and guidance counselors directly, there is very little in the way of outreach to parents, who, after all, still have an incalculable impact on their children's values and aspirations. ${ }^{27}$

Recently, it has become clear that another barrier to attracting talented youth to careers in engineering is that engineering firms, with their traditional base of male employees, do not tend to have family-friendly corporate cultures. It is well known that many women who do enter engineering careers feel compelled to drop out within their first ten years. ${ }^{28,29,30,31}$ The National Council for Research on Women (NCRW) report "Balancing the Equation: Where Are Women and Girls in Science, Engineering and Technology" notes, "women are twice as likely to leave science and engineering jobs for careers in other fields. ${ }^{32}$ While some, like Harvard president Lawrence Summers, might hypothesize that women are intrinsically less interested in highpowered careers, and might even be less well-endowed genetically in science, math and engineering capability, ${ }^{33}$ others caution us to look first to the historic, social and cultural evolution of family, society, academic, and corporate culture. Indeed, industry councils are now beginning to take a look at what kind of changes would need to be made in order to adapt to a two-career family culture. ${ }^{34}$

Robert Chang has commented that the current gender gap may in any case soon fall, partly based on revitalized education practices. Based on his research with the Materials World Modules Program at Northwestern University, Chang has learned that high school girls excel in relating science concepts to design projects - processes more akin to the way professional engineers operate in the real world. ${ }^{35}$

In his role as P.I. of the NSF-funded National Center for Learning and Teaching Nanoscale Science and Engineering, Chang is spearheading a new effort to develop, test, and implement innovative nano-centered STEM curricula in secondary schools. The National Science Foundation's decision to fund the NCLT is a further example of the way in which the National Nanotechnology Initiative is catalyzing new developments in engineering education with far-

"Proceedings of the 2005 American Society for Engineering Education Annual Conference \& Exposition Copyright (C)2005, American Society for Engineering Education” 
reaching impacts. The next question to consider will be where these new educational opportunities will fit into the nation's secondary school curricula.

Currently, Massachusetts is the only state in the U.S. that has included a set of engineering standards along with testing and curricula guidelines for K-12. ${ }^{36}$ (Some other states, such as New York, have also included engineering in their standards.) Ioannis Miaoulis, former dean of Tufts University School of Engineering, was instrumental in Massachusetts' adoption of engineering as part of the state's Science and Technology Frameworks. Miaoulis, now the president and director of the Museum of Science, Boston and head of the National Center for Technological Literacy housed at the Museum of Science, is pursuing a national effort to institute K-12 engineering standards in all fifty states. ${ }^{37}$

Even with better teacher preparation and curricula, however, the current national K-12 emphasis on test-based accountabilities has had the effect of diminishing the incentive for increased science and engineering classroom time. In Massachusetts, for example, K-6 testing concentrates on math and literacy. Teachers must spend their limited classroom time making sure their students achieve adequate scores in these areas.

Some universities reach out directly to K-12 students, through NSF-funded GK-12 and other programs. The University of New Hampshire operates Project SMART. ${ }^{38}$ This four-week-long Summer Institute "challenges, educates, and motivates talented high school students in science and math." The students are "exposed to advanced topics in selected areas of science in an interdisciplinary way through lectures, demonstrations, hands-on laboratory experience, and field trips and learn the process of research with faculty and graduate students." The program is open to students currently enrolled in the 10th or 11th grades, and will be developing a nano section in the near future.

The Northeastern University Young Scholars Program ${ }^{39}$ offers future scientists and engineers a unique opportunity for hands-on research experiences while still in high school. This six-week summer program is open to Greater Boston area applicants who have completed their sophomore or junior year in high school. Students earn $\$ 150$ per week working in research laboratories within Northeastern University's Colleges of Arts and Sciences and Engineering. They are exposed to the 'nuts and bolts' of careers through field trips to a variety of corporate and government sites where they see and speak with scientists and engineers in action. Destinations have included Raytheon, Biogen Idec, Genzyme,Harbor Explorations, Massachusetts General Hospital, and the U.S. Army Natick Research, Development, and Engineering Center.

University of Massachusetts Lowell has developed a week-long summer Nanotech Camp for students in grades 5 through 10 and is developing a two-week advanced version for high school students. Based on this work, UML and Northeastern will collaborate to design "NanoManufacturing Camp" to be launched in 2006. ${ }^{40}$

"Proceedings of the 2005 American Society for Engineering Education Annual Conference \& Exposition Copyright (C)2005, American Society for Engineering Education” 


\section{Teacher Preparation}

Providing adequate preparation for teachers is another major challenge in the K-12 field, particularly for those teaching math and science at the K-8 level. Middle school teachers must now be subject-certified, but there is little money to pay for their training and few salary incentives for recovery of such an investment. One promising approach, "Project Excel," was developed by Anita Greenwood in the College of Education at University of Massachusetts Lowell. Greenwood received a Robert Noyce Foundation grant to train engineers as K-12 teachers, adding on an M.S. in Education after their B.S. ${ }^{41}$

Many universities make contributions in this area by running NSF-funded Research Experience for Teachers (RET) programs. These RETs afford secondary school teachers the opportunity to immerse themselves in real research at the university level, and the excitement and insight they bring back to their classrooms is, at least anecdotally, significant. Said Cambridge high school teacher Colleen O'Shell, who participated in one of Harvard's Department of Engineering and Applied Sciences' RETs:

My RET experience gave me the opportunity to get back in touch with the current research that is happening in my field (chemistry). I was able to show my students the lab notebook I kept over the summer so they could see how science is really done...lots of rejected hypotheses, countless trials of the same experiment, and months worth of work for only one experimental question! This is in stark contrast to the typical high school chemistry experience where labs are neatly packaged into one class session where small sets of data are collected by following a tried and true cookbook recipe of a chemical principle discovered hundreds of years ago! Not to say that these types of labs have no merit, but unfortunately, this type of experience over 12 years of science education enable students to have deep misconceptions of how science is really done. My hope is that the insight I have gained and shared with my students has shed some light on how they think about learning science and science research. ${ }^{42}$

Fellow participant Christina Talbot added,

My RET experience gave a substantial boost to the excitement I bring to the classroom. I found the university research led reinforcement to the curriculum taught. The exposure to current scientific developments by fellow teachers and undergrads provided a hands-on opportunity to share with students up-to-date research topics. The constant networking with faculty and fellow teachers offered occasion to glean teaching methods, material and demonstrations. ${ }^{43}$

RET programs can also help lay the foundation for the development of the next generation of science teacher leaders. RET participants from across the country meet annually at a Northeastern University/NSF supported pre-conference coordinated with the National Science Teachers Conference (NSTA) to network, share connections to their classrooms and also to

"Proceedings of the 2005 American Society for Engineering Education Annual Conference \& Exposition Copyright $\mathbb{C} 2005$, American Society for Engineering Education" 
document for university partners common characteristics of successful research based professional development programs. ${ }^{44}$

Yet training teachers and recruiting and educating tomorrow's nanoscale scientists and engineers represents only part of the equation. Another significant part is educating and informing the nation's citizenry - including business and community leaders, moms and dads, elected officials, the media, social scientists, and ethicists - on these new technologies transforming our world, and engaging these citizens in envisioning the kind of world we hope to shape through these technologies.

\section{Public Engagement with Research in an Emerging Nanotech World ${ }^{45}$}

\section{"We shape our tools and thereafter our tools shape us." - Marshall McLuhan}

Nanotechnology, with its convergence of fundamentals in physics, chemistry, biology, computing and engineering, may well require, as well as help to inspire a reorganization of the nation's science and engineering curricula, but this can occur only at a slow and uneven pace across the patchwork of independent school districts and universities that make up the nation's formal education "system." In the meantime, science museums, and other informal science education institutions, may be able to make substantial contributions to developing imaginative new curricular approaches. William Frascella, former NSF-ESIE Director and Chair of the NSEE Coordinating Committee, has characterized the nation's science museums as "the Fermilabs and Brookhavens of educational research." 46 In January 2005, NSF sanctioned this idea by issuing a request for proposals for the development of a Nanoscale Informal Science Education Network to catalyze R\&D in this growing informal science education sector.

America's science centers and museums have the potential to reach significant populations beyond school field trip groups with interactive exhibits and programs. A whopping $66 \%$ of American adults surveyed in 2001 reported that they had visited a science or technology museum at least once during the past year. This figure has been rising since $1983{ }^{47}$ While traditionally regarded as destinations for school field trips and family weekend entertainment, science museums have also begun to emerge in recent years as venues well-suited for continuing adult engagement with science and technology and as ideal educational outreach partners for university and institute-based researchers.

Science museums might also potentially provide those missing public spaces where researchers, policymakers, representatives of interest groups, and citizens can engage in forums, discussions, and facilitated consensus-building activities on the development and deployment of new technologies. Such activities have been prototyped at La Cite des Sciences et de l'Industrie in Paris, the Science Museum in London, and the Museum of Science, Boston - addressing issues of heightened public concern such as genetics testing, genetically modified food technology, stem cell research, and now nanotechnology.

Engaging public and school audiences in nanotechnology is challenging: even the most basic explanation seems to require a parenthetical statement (to explain the scale indicated by the 
prefix nano, for example, or that atoms are building blocks of matter, whatever that is). Nanotech is hard to pin down in a brief non-technical description. It is everything, it seems - an umbrella term - but it is also nothing - nothing one can see, hear or feel. The scale is incomprehensible, the language inaccessible. Effective communication of nanoscale processes even with the aid of metaphors, analogies, and rich graphics - seems to require the assumption of a certain set of shared a priori experiences as well as extraordinary conceptual abilities. Yet these apparent cognitive barriers to nanotech communication mask an even more formidable threat, a widespread cultural phenomenon: science and math phobia.

Most people believe that physics, for example, is beyond their reach; at best, a foreign country where only geniuses dare tread; at worst, an irrelevant and wasteful mental exercise. Popular culture tends to relieve the tension by elevating the very human Einstein to a pantheon of superhuman icons, revered as God-like savants, thus allowing the rest of us to stick to what we mere humans do best (i.e., not physics). As for the irrelevant and wasteful mental exercise strand of thought, here is a quote from former Senate Majority Leader Trent Lott, addressing an audience of high school and college students on C-Span in January 1997, and clearly winning their approval:

"When I was in high school, if you were in the so-called pre-college curriculum, you had to take four years of science and four years of math: a waste of my time, a waste of the teacher's time, and a waste of space. You know, I took physics... for what?" (Cheers, laughter, applause). ${ }^{48}$

Indeed, the National Science Board's Science and Engineering Indicators show that few American adults know what an atom or a molecule is, nor which is composed of the other. Only $13 \%$ were able provide a correct explanation of a molecule. ${ }^{49}$ Jon Miller, the principal investigator, commented:

This result is both surprising and troublesome. The term molecule has become a part of journalistic discourse on television and is often used in newspaper articles without additional explanation. An analysis of the open-ended responses indicated that many adults knew that molecules were very small, but did not know whether atoms were composed of molecules or molecules were composed of atoms. Some individuals knew that a molecule was a basic building block and was very small, but could not say anything else about it. ${ }^{50}$

In other words, forget physics, forget chemistry, and forget molecular biology. Miller concluded, "Minimally, it is essential that science communicators recognize the limited nature of public understanding of the structure of matter..." A Chicago Museum of Science and Industry front-end study for a nanotechnology exhibit corroborated the finding of general public unease with terms like atom, molecule, and matter. ${ }^{52}$

As a result, mentioning a fundamental nanotech notion like "building a transistor atom by atom," may result in a massive audience attention loss. What's an atom? What's a transistor? In this climate, one is quickly dissuaded from venturing on to interpret other key areas of nanotech research involving, say, quantum dots, scanning tunneling microscopy, or spintronics.

"Proceedings of the 2005 American Society for Engineering Education Annual Conference \& Exposition Copyright (C)2005, American Society for Engineering Education” 
Clearly, one of the challenges with nanotechnology is to find multiple pathways to penetrate physics phobia, providing entry points to this rarified world beyond the senses, and empowering public and school audiences with the experience of constructing and testing their own inquirybased conceptual models. The increased confidence this learning process may engender could go a long way toward making public dialogue on societal concerns a real possibility, and may also open the door to further individual engagement and learning.

Cognitive penetration of the nano world may require something beyond the normal textbook or classroom lecture experience approach. Because that world is so counter-intuitive, so contrary to practical experience and so inaccessible to the senses, new multi-dimensional approaches should be explored, possibly involving large-scale interactive models enhanced by audio-visual media, and kinesthetic, sensory, and motor experiences. The task demands expert and research-saavy communicators, skillful at creating mental and physical analogs for atomic-scale processes and making them centrally relevant to diverse audiences.

Science centers and museums are beginning to serve as laboratories for testing innovative methods of teaching and learning nanoscale science and exploring cognitive connections. Most program and exhibit designers take visitor research very seriously. Front-end studies help determine what potential audiences already understand about any given subject and what associations it holds for them. Typically, exhibit designers move slowly, in frequent communication with the target audience, carefully prototyping and making iterative adjustments of exhibit concepts and activities as they proceed through the development process.

Nevertheless, most of the exhibits exploring nanotechnology thus far have concentrated on tackling the issue of scale (how small is a nanometer?) or display of fairly trivial consumer outcomes (e.g. nanopants, sunscreens, tennis rackets). In the excitement to plunge ahead into the brave new world of nano, exhibit designers have not always considered at the outset what level of cognitive development is required to understand the necessary abstractions. An NSF-funded exhibit on nanotechnology, targeted at 5-8 year-olds it funded, became a hit at the Epcot Center. However, the exhibit planners found out in the prototyping process that this age group had trouble conceiving objects smaller than a red blood cell. ${ }^{53}$ While entitled "It's a Nano World," the exhibit was in its final version, able to focus on the notion of scale only to the micron level. A follow-up exhibit, "Too Small to See," will be targeting a middle school audience and will be testing new concepts for taking children through that further vast conceptual leap to the nanoscale. $^{54}$

A program of educational outreach developed by the Current Science \& Technology Center at the Museum of Science Boston, in collaboration with the Nanoscale Science and Engineering Center headquartered at Harvard University, ${ }^{55}$ targets teens and adults for its nanoscale research interpretive activities. This program concentrated not on exhibits, but on a continuing series of live staff and guest researcher presentations, augmented by multimedia, and delivered on the main floor of the Museum. Nanotech-related presentations developed by CS\&T staff members Joel Rosenberg and Daniel Davis have titles such as The Wonderful (and not so wonderful) World of Carbon Nanotubes, The Incredible Shrinking Transistor, Hooked on Photonics, and Nanomedicine. They begin with compelling ideas that link the subjects immediately to personal

"Proceedings of the 2005 American Society for Engineering Education Annual Conference \& Exposition Copyright (C)2005, American Society for Engineering Education” 
experience, include a little history, a core of science, a dose of personality, and a glimpse of future directions. These lively twenty-minute multimedia and prop-rich stage events are often followed by more intimate Q\&A and discussion, and they attract a good teen and adult audience. ${ }^{56}$ Evaluators determined that the face-to-face approach worked well with engaging audience attention and retention of key concepts. ${ }^{57}$ The Museum also curates a guest researcher speaker series, working closely with the researchers to adapt their more typically academicstyled presentations to a style that works with our diverse audiences. Some of the presentations have been videotaped and edited and posted on the website at mos.org/nano. ${ }^{58}$

More recently, the Museum added live cablecasting capability to the CS\&T stage, and by arrangement with New England Cable News, provides a weekly "SciTech in the News" program which frequently focuses on nanoscale research, and reaches up to 2.8 million homes and businesses. The success of these outreach activities earned top marks from the Harvard NSEC's NSF Visiting Committee, ${ }^{59}$ and it is clear that NSF wants to encourage embedding many such informal science education partnerships into its research center initiatives.

The current launch of a new collaboration between the Museum of Science and the NSF-funded Center for High-Rate Nanomanufacturing - a partnership between Northeastern University, the University of Massachusetts Lowell, and the University of New Hampshire - will serve to leverage both Centers' efforts to fulfill their public outreach mission. The CHN partnership will, in particular, expand the scope of these experimental nanoscale science and engineering interpretive activities so that their content can span the gamut from theory to practice - from understanding electron behavior at the quantum level to developing successful nanomanufacturing templates for commercial production. In other words, the Museum anticipates being able to convey to its broad audiences the grand view of our nation's investment in the nanoscale science and engineering enterprise, from basic research to human benefit.

Besides targeting public audiences, the university-museum partners will also focus on K-12 professional development. In November 2005, in partnership with CHN, the Harvard-based NSEC “Center for Science of Nanoscale Systems and their Device Applications," and Boston University, the Museum will hold its first Nanotech Symposium for Teachers and Guidance Counselors. This one-day event will be modeled on the Museum's successful annual Biotech Symposium for Teachers. RET program directors at the universities along with some of their RET alumni will help museum staff in planning a day that will focus directly on the needs of secondary school teachers.

Another professional development area being explored for partnership focus is in enhancing public communication of science skills for university students and post-docs. Building capability in this area will have long-term impacts on the future of research communication and public understanding of science. One approach will be to provide internships in science and engineering communication for engineering students at the Museum of Science. This program will be organized through Northeastern's industry co-op placement program. The message to students is that successful public communication skills may be as important as workplace literacy.

"Proceedings of the 2005 American Society for Engineering Education Annual Conference \& Exposition Copyright (C)2005, American Society for Engineering Education” 
$\mathrm{CHN}$ and the Museum of Science also plan to work together to develop programs on societal implications and ethical considerations of nanotechnology for use both in university settings and public forums at the Museum. The Museum has been developing plans with the NanoCenter at the University of South Carolina to develop and disseminate a science museum-based version of the South Carolina Citizens' School of Nanotechnology. The Museum will partner locally with $\mathrm{CHN}$ and the Harvard NSEC to design and implement the initial science museum-based model. This venture could help pioneer a new function for science museums as adult education and forum spaces for increasing community awarenessof the research being undertaken locally and its connection to the national nanotechnology R\&D enterprise. The Citizens' Schools concept may help to open a door to continuing engineering education for adult audiences in a way that also enhances public participation in the national conversation over the potential benefits and risks of new technologies and the institution of safe and fair regulatory practices.

$\mathrm{CHN}$ has set aside funds for research and evaluation of our informal science educational outreach efforts, and we expect to be reporting at a later date the findings from our initial period of work.

NanoNetworking: Pulling it All Together

"The purpose of models is not to fit the data but to sharpen the questions." - Samuel Karlin

As these New England-based partnership efforts evolve and grow, the collaborators will be looking for new opportunities to stimulate further sharing of best practices developed by formal and informal nanoscale science and engineering educators across the entire field, nationally. There is increasing recognition of the need to explore new ways to network the formal and informal science education communities, pooling together their research, resources and prior experience in nanotech education and building on best practices. With education and outreach funding so scarce, educators cannot afford to repeat failed experiments.

The recent decision of the NSF to fund a Nanoscale Informal Science Education Network which will work closely with the already-funded Nanoscale Learning and Teaching Center based at Northwestern University - promises to catalyze further development across the entire nanotech education field. Targeting public audiences for nanoscale informal science education will help prepare the soil for the necessary development of citizen engagement in setting the direction and context for the nanotech revolution. It will also help to provide the essential context required for educational reform, student and teacher recruitment, improvement in university engineering educational practices, and continuing progress in nanotech R\&D. Seeded in all of this wellprepared soil, innovations critical to our future may safely begin to bear fruit. 


\section{Author Biographical Information}

CAROL LYNN ALPERT is Director of Strategic Projects for the Museum of Science, Boston, and directs the program of informal science education activities for CHN and for the Harvard-MIT-UCSB-MOS Nanoscale Science and Engineering Center. Alpert led the team that created Museum's award-winning Current Science \& Technology Center and is working on developing new techniques for broader collaborations on nano public outreach activities.

JACQUELINE A. ISAACS is an Associate Professor in the Department of Mechanical and Industrial Engineering at Northeastern University in Boston, MA. She is responsible for the education and outreach activities as well as research on societal implications for the NSF-sponsored Center for High-rate Nanomanufacturing (CHN), a collaborative Center among NU, UML and UNH. Her research focuses on economic and environmental assessment of manufacturing.

CAROL M. F. BARRY is an Associate Professor in the Department of Plastics Engineering at the University of Massachusetts in Lowell, MA. For CHN and at UML, she is the lead for the education and outreach activities for the NSF-sponsored CHN. Her research focuses on plastics processing, particularly at the micro and nanoscales and their application to high-rate nanomanufacturing.

GLEN P.MILLER is an Associate Professor in the Department of Chemistry at the University of New Hampshire in Durham, NH. An Associate Director of the Center for High-rate Nanomanufacturing, he is responsible for the education and outreach activities at UNH. His research interests include fullerene chemistry, the synthesis and study of bisfullerene [60] compounds containing 2 C60 moeities, and Diels-Alder reactions with fullerenes.

AHMED A. BUSNAINA is the William Lincoln Smith Professor in the Department of Mechanical and Industrial Engineering at Northeastern University. He is the Director of the NSF-sponsored Center for High-rate Nanomanufacturing (CHN). His research focus is in semiconductor manufacturing processes with an emphasis on nanofabrication and in wafer cleaning technology.

\section{References}

(web references and personal communications from Jan/Feb 2005)

${ }^{1}$ The National Nanotechnology Initiative Strategic Plan, developed by the Nanoscale Science, Engineering and Technology Subcommittee of the Committee on Technology of the National Science and Technology Council, December 2004, available at nano.gov.

${ }^{2}$ See, for instance, "National Nanotechnology Initiative; Research and Development Supporting the Next Industrial Revolution, Supplement to President's FY 2004 Budget, Oct. 2003," available at nano.gov.

${ }^{3}$ The National Science Foundation has hosted two workshop/conferences on the societal implications of nanotechnology, the first in March 2001 and the second in December 2003. The report from the first workshop is available at www.wtec.org/loyola/nano/NSET.Societal.Implications; the report from the second workshop will be published very soon. First author (Alpert) participated in the second workshop.

${ }^{4}$ George Whitesides offered this qualification in person to first author (Alpert).

${ }^{5}$ A December 2001 workshop was held by the National Science Foundation and the Department of Commerce at which leading experts from government, the academic research community and the private sector explored the nature and size of the potential opportunities in NBIC convergence (nanoscience, biotechnology, information technology and cognitive science). The workshop concluded that NBIC "offers immense opportunities for the improvement of human abilities, social outcomes, the nation's productivity and its quality of life; it also represents a

"Proceedings of the 2005 American Society for Engineering Education Annual Conference \& Exposition Copyright (C)2005, American Society for Engineering Education” 
major new frontier in research and development." The report recommended that an R\&D initiative focusing on enhancing human performance (while governed by respect for human welfare and dignity) should become a national priority.

${ }^{6}$ Sheryl L. Duggins and Barbara Bernal Thomas, "An Historical Investigation of Graduate Software Engineering Curriculum, Proceedings of the $15^{\text {th }}$ Conference on Software Engineering Education and Training (CSEET.02) 1093-0175/02 (2002).

${ }^{7}$ Edward A. Lee and David G. Messerschmitt, "Engineering an Education for the Future," IEEE, 0018-9162/98 (1998).

${ }^{8}$ William H. Schmidt, Curtis C. McKnight, and Senta A. Raizen, A Splintered Vision: an Analysis of U.S. Mathematics and Science Curricula, Kluwer Academic Publishers (1998).

${ }^{9}$ National Science Board, "Preparing Our Children: Math and Science Education in the National Interest," http://www.nsf.gov/nsb/documents/1999/nsb9931/nsb9931.htm.

${ }^{10}$ Gilbert A. Valverde and William H. Schmidt, "Refocusing U.S. Math and Science Education," Issues in Science and Technology On-line (1997), http://www.issues.org/issues/14.2/schmid.htm.

11 "Issue Brief: Degrees earned by foreign graduate students: Fields of study and plans after graduation," National Center for Education Statistics, November, 1997, http://nces.ed.gov/pubs98/web/98042.asp.

12 "Financial Aid Profile of Graduate Students in Science and Engineering," National Center for Education Statistics, March, 2000, http://nces.ed.gov/pubsearch/pubsinfo.asp?pubid=200011.

${ }^{13}$ Stanley Williams speech at MIT's "Emerging Technologies" conference 2003, noted by first author Alpert.

${ }^{14}$ For example NSF 04-523, "Grants for the Department-Level Reform of Undergraduate Engineering Education"

15 "Program outcomes (a through k) that describe what students are expected to know or be able to do by the time of graduation include (d) an ability to function on multi-disciplinary teams and (h) the broad education necessary to understand the impact of engineering solutions in a global and societal context." -- Criteria for Accrediting Engineering Programs during the 2004-2005 Accreditation Cycle", Engineering Accreditation Commission, ABET, Inc., Baltimore, MD, website: www.abet.org, Last Accessed February 26, 2005.

${ }^{16}$ For example, NSF 05-532 "Ethics Education in Science and Engineering."

${ }^{17}$ NSF 04-043 "NSEC: Center for Nanotechnology and Society."

${ }^{18}$ Cohen, P., McDaniels, M., and D. Qualters, “AIR: A teaching tool for cultivating reflective ethical inquiry," College Teaching, (in press, 2005).

${ }^{19} \mathrm{C}$. Cunningham communication with first author (Alpert).

20 "Maintaining a Strong Engineering Workforce," a study by the ACT, reported:

- a drop in the number of high school seniors planning to study engineering, from 9 percent in 1992 to 6 percent in 2002;

- a decrease in the percentage of students interested in engineering who had taken college preparatory courses in high school;

- a drop in the number of female ACT test takers considering engineering careers;

- a gap between aspirations of racial/ethnic minority test takers, as indicated by expressed interest in engineering, and their relevant preparation with more than basic coursework.

21 "Balancing the Equation: What We Know and What We Need," from Mary Thom, "Balancing the Equation: Where Are Women \& Girls in Science, Engineering \& Technology?" (2002) http://www.ncrw.org/research/scifacts.htm.

"Proceedings of the 2005 American Society for Engineering Education Annual Conference \& Exposition Copyright (C)2005, American Society for Engineering Education” 
${ }^{22}$ The report "Building Human Capital, A New England Strategy" (Michael K. Thomas, Robert Weygand, Paul E. Harrington) states, "students who complete rigorous mathematics courses are much more likely to go on to college than those who do not. Specifically, $83 \%$ of students who took Algebra 1 and Geometry went on to postsecondary education within two years of high school graduation, compared with only 36 percent of students who did not take such courses. Sadly, failure to lay these "building blocks" neglects the foundation of students' academic achievement and their future workforce opportunities."

${ }^{23}$ Meredith Knight communication with author C. Barry on Tufts NSF PCET findings.

${ }^{24} \mathrm{C}$. Duggan communication with first author (Alpert).

${ }^{25}$ To read the CED report, visit: http://www.ced.org/projects/scientists.shtml

26 "American Perspectives on Engineers and Engineering," Harris Poll conducted for the American Association of Engineering Societies, February 13, 2004, http://www.aaes.org/harris_2004_files/frame.htm.

${ }^{27}$ R.P.H. Chang communication with first author (Alpert).

${ }^{28}$ Sue V. Rosser, The Science Glass Ceiling, Routledge, New York, NY, 2004.

${ }^{29}$ Virginia Valian, Why So Slow? The Advancement of Women, M.I.T. Press, Cambridge, MA (1999).

${ }^{30}$ Deborah Leigh Wood, “The Fight Goes On," Graduating Engineer and Computer Careers Online," November , 2001, http://www.graduatingengineer.com/articles/women/11-13-01.html.

${ }^{31}$ Andrew Lawler, "Women Engineers Marginalized," ScienceNOW, 2 (2002), http://sciencenow.sciencemag.org/cgi/content/full/2002/320/2.

${ }^{32}$ Mary Thom, "Balancing the Equation: Where Are Women \& Girls in Science, Engineering \& Technology?," National Council for Research on Women, 2002.

${ }^{33}$ L. H. Summers, "Remarks at NBER Conference on Diversifying the Science \& Engineering Workforce," Cambridge, Mass, Jan. 14, 2005. Accessed from Harvard University website.

${ }^{34}$ The following recommendations are made in "Balancing the Equation, What we know and What we need, " http://www.ncrw.org/research/scifacts.htm:

- Leadership support for family-friendly policies: employers must establish and promote family-friendly policies, and top executives should encourage male and female employees to take advantage of those policies.

- Fair hiring and promotion practices: Employers must stop practice of biased hiring and promoting policies based on a perceived risk associated with promoting women.

- Businesses need to end practices that set a double standard for measuring men's women's achievement.

${ }^{35}$ R.P.H. Chang, op. cit. This as-yet unpublished study was based on the field tests of 31,000 high school students in 47 states.

${ }^{36}$ C. Cunningham, op. cit.

${ }^{37}$ The current agenda of the National Center for Technological Literacy in the K-12 arena, according to Christine Cunningham, VP for Research at the Museum of Science, includes the following:

(1) Advocacy and Standards Development: Collaboration with state leaders to help states introduce or modify standards related to technology and engineering,

(2) Curricular Materials: Providing educators with cutting-edge curricular resources for teaching engineering and technology.

"Proceedings of the 2005 American Society for Engineering Education Annual Conference \& Exposition Copyright $\mathbb{C} 2005$, American Society for Engineering Education” 
○ Elementary School Materials: Developing "Engineering is Elementary:

Engineering and Technology Lessons for Children" curriculum. Elementary teachers nationwide can use these materials to teach technology and engineering concepts to children grades 1-5.

$\circ$ High School Materials: Developing the Engineering the Future: Designing the World of the $21^{\text {st }}$ Century curriculum for high school students. The student and teacher materials encourage high school students to explore what engineering and technology are and how they impact our society.

(3) Educator Resource Center: Creating an Educator Resource Center that houses technology and engineering curricular materials. After training by NCTL staff, educators from the state assess the materials to evaluate how well they meet that state's standards. These data are available in the online ERC so educators across the state can benefit from this analysis. See mos.org/doc/1369

(4) Professional Development: NCTL staff work in partnership with local or state teacher educators to provide professional development for teachers about engineering and technology.

${ }^{38}$ See http://www.smart.unh.edu.

${ }^{39}$ See www.youngscholars.neu.edu.

${ }^{40}$ NanoTech Camp is an extension of the UML's highly successful DesignCamp (UMass Lowell DesignCamp, http://designcamp.caeds.eng.uml.edu), a series of week-long hands-on, science and engineering summer workshops held each July for students in grades 5 through 10. UML is currently developing a two-week advanced program designed for high school students. Using principles of this program, UML and NEU will jointly develop one or two-week "NanoManufacturing Camps" during the summer of 2005 that will be implemented in the summer of 2006. (Info provided by Douglas Prime to author C. Barry.)

${ }^{41}$ Candidates must 1 ) have an undergraduate or graduate degree in a field of science, engineering, or mathematics, 2) commit to teaching for two years in a HIGH NEED school district, and 3) be a US citizen or resident alien. Greenwood reports, however, that it has been difficult to recruit teachers, chiefly because they do not want to commit to working in difficult "high-need" school environments for two years. The market for science and math teachers is so robust that new teachers can easily find jobs in more desirable school districts. In the first year of the grant, most of the takers were older career changers, and in fact, a large percentage of new teaching students in graduate school of education - even outside the Excel program - are careerchangers. Reported by A. Greenwood to author C. Barry.

${ }^{42}$ Colleen O'Shell email to first author (Alpert).

${ }^{43}$ Christina Talbot email to first author (Alpert).

${ }^{44}$ www.ret.neu.edu

${ }^{45}$ This section includes some excerpts from a paper C. L. Alpert submitted for the Societal Implications of Nanotechnology workshop, held Dec. 3-5 at NSF in Arlington, VA. The paper was entitled "Public Engagement with Nanoscale Science and Engineering," and will be included in the proceedings of the workshop under the heading "Governance."

${ }^{46}$ Talk given as member of panel on nanotech museum exhibits organized by first author (Alpert) at the annual meeting of the Association of Science-Technology Centers, October 2004, San Jose.

"Proceedings of the 2005 American Society for Engineering Education Annual Conference \& Exposition Copyright (C)2005, American Society for Engineering Education” 
${ }^{47}$ J.D. Miller, "Public Understanding of and Attitudes toward Scientific Research: What We Know and What We Need to Know: A Report to the National Science Foundation, " May 31, 2002.

${ }^{48} \mathrm{C}-$ Span 1-18-97. I am indebted to Eric Mazur for alerting me to this cablecast. (Alpert)

${ }^{49}$ J. D. Miller, 2002, based on the NSB 2000 indicators. [Interestingly, the NSB 2002 indicators seem to put the figure at $22 \%$, which Miller remarks on in a footnote, suggesting that the discrepancy between the NSB 2000 and the NSB 2002 figures may be due to a new way of recording respondents' answers. Also, the 2002 survey also showed that only about half the respondents knew that electrons were smaller than atoms. Miller's conclusion still seems valid.] ${ }^{50}$ J. D. Miller, 2002.

${ }^{51}$ J. D. Miller, 2002.

${ }^{52}$ Jill Gilmartin, "Nanotechnology: Front-End Evaluation Report" prepared for the Museum of Science and Industry, Chicago and the Northwestern University Nanoscale Science and Engineering Center, (NU-NSEC) 2002. Unpublished; obtained from project director, Barry Aprison.

${ }^{53}$ J. D. Miller, 2002.

${ }^{54}$ These exhibit projects have been developed by the ScienCenter, Ithaca, and Main Street Science, with funding from NSF.

55 "Science of Nanoscale Systems and Their Device Applications" NSEC, Harvard-MIT-UCSBMOS. P.I. Robert Westervelt, http://www.nsec.harvard.edu/

${ }^{56} \mathrm{See}$, for example, http://www.mos.org/cst/article/4656/, which is also linked to from the www.nano.gov educators' resources page.

${ }^{57}$ Martin Storksdieck, Institute for Learning Innovation, unpublished formative evaluation report given to first author (Alpert).

${ }^{58}$ See, for example, Eric Mazur on femtosecond laser research at http://www.mos.org/cst/article/5339/ (Researchers who have the knack for engaging lay audiences with their excitement, accomplishments and motivations in accessible language are everywhere to be sought out and emulated, as they provide a key link in the process. Graduate students too ought to be encouraged to develop their communication skills - not only will it help us bridge this two-cultures gap, but it will also help them write grants, attract venture capital, and feel more at ease at cocktail parties.)

59 " The Center demonstrated a very strong commitment to its educational and outreach mission, and should be commended for introducing a truly outstanding program in collaboration with the Boston Museum of Science. This program serves as a focal point of the Center's educational outreach activities by coupling the scientific expertise of the technical investigators at MIT and Harvard with the energetic and enthusiastic communicators of science and technology information at the Boston Museum.... In addition to developing and delivering live "shows" on topics including transistor scaling, carbon nanotubes, and photonics, the Center has also developed equally impressive annotated displays that are loaded onto touch screen Kiosks placed in the Museum. This program has the ability to expose a vast cross-section of people throughout the Boston area to the excitement of science and technology. The Center should also be applauded in their initial attempts to disseminate this information to other Museums throughout the country, which will further enhance national impact.” NSF Site Visit Report, July 1, 2003.

"Proceedings of the 2005 American Society for Engineering Education Annual Conference \& Exposition Copyright $\mathbb{C} 2005$, American Society for Engineering Education" 